\title{
Effect of supplementing orchardgrass herbage with a total mixed ration or flaxseed on fermentation profile and bacterial protein synthesis in continuous culture
}

\author{
K. J. Soder, ${ }^{* 1}$ A. F. Brito, $†$ and M. D. Rubano* \\ *US Department of Agriculture-Agricultural Research Service, Pasture Systems and Watershed Management Research Unit, \\ University Park, PA 16802 \\ †Department of Biological Sciences, University of New Hampshire, Durham 03824
}

\begin{abstract}
A 4-unit dual-flow continuous culture fermentor system was used to evaluate the effects of supplementing fresh herbage with a total mixed ration (TMR) or flaxseed on nutrient digestibility, fermentation profile, and bacterial $\mathrm{N}$ synthesis. Diets were randomly assigned to fermentors in a $4 \times 4$ Latin square design. Each fermentor was fed a total of $70 \mathrm{~g}$ of dry matter/d of 1 of 4 diets: (1) 100\% freeze-dried orchardgrass herbage (Dactylis glomerata L.; HERB), (2) 100\% freezedried TMR (100TMR), (3) 50\% orchardgrass herbage supplemented with 50\% TMR (50TMR), or (4) $90 \%$ orchardgrass herbage supplemented with $10 \%$ ground flaxseed (Linum usitatissimum L.; FLAX). Preplanned, single degree of freedom orthogonal contrasts were constructed to assess the effects of feeding system (HERB vs. 100TMR), herbage supplementation (HERB vs. 50TMR + FLAX), and herbage supplemental source (50TMR vs. FLAX). Compared with the HERB diet, the 100TMR diet significantly reduced apparent digestibility of neutral detergent fiber. Herbage supplementation with 50TMR or FLAX significantly reduced or tended to reduce apparent digestibilities of dry matter, organic matter, and neutral detergent fiber, suggesting that replacing high-quality, highly digestible fresh herbage with forage TMR likely caused depressions in nutrient digestibilities. Concentration of total volatile fatty acids, molar proportions of acetate, propionate, and isovalerate, as well as the acetate:propionate ratios were all significantly higher in fermentors fed 100TMR compared with HERB, likely in response to enhanced supply of fermentable energy. In general, feeding system, herbage supplementation, and type of supplementation did not affect $\mathrm{N}$ metabolism in the present study. The few significant changes in $\mathrm{N}$ metabolism (e.g., flows of
\end{abstract}

Received October 24, 2012.

Accepted February 10, 2013.

${ }^{1}$ Corresponding author: kathy.soder@ars.usda.gov total $\mathrm{N}$ and non- $\mathrm{NH}_{3}-\mathrm{N}$ ) were primarily linked to increased fermentor $\mathrm{N}$ supply with feeding herbage-based diets (HERB and FLAX). Although TMR-based diets decreased nutrient digestibility slightly, TMR offered advantages in bacterial fermentation in relation to volatile fatty acid production, which could potentially translate into better animal performance. Flaxseed shows promise as an alternative supplement for herbage-based diets; however, further in vivo evaluation is needed to determine the optimal level to optimize animal production while reducing feed costs.

Key words: flaxseed, herbage, in vitro fermentation, total mixed ration

\section{INTRODUCTION}

In general, dairy cows that are fed a nutritionally balanced TMR usually experience a significant decline in milk production when transitioned to herbage-based diets (Bargo et al., 2002a; White et al., 2002). One of the primary reasons for explaining this reduction in milk production is the low energy density found in most temperate pastures, which comprise primarily cool-season grasses (Bargo et al., 2002a). Therefore, many dairy farmers feeding herbage during the grazing season (April to October in the northeastern United States) also use TMR containing alfalfa haylage or corn silage in addition to concentrate as a major supplemental source. In fact, the use of TMR can boost not only energy to support high milk production, but also effective fiber, yielding a more stable ruminal environment (Bargo et al., 2002b; Soder and Muller, 2007). More recently, interest has increased in supplementing herbage-based diets strictly with a single energy source such as corn meal or molasses (Ross et al., 2011) or flaxseed (Scholljegerdes and Kronberg, 2010; Soder et al., 2012). Although corn has been the most popular energy source fed on northeastern dairy farms, escalating prices due to the shift of corn use from animal feeding to ethanol production have prompted dairy farmers to seek alternative sources of supplemental energy. 
Flaxseed is an oilseed rich in the n-3 FA $\alpha$-linolenic acid (Ambrose et al., 2006), which is known to be transferred to milk (Caroprese et al., 2010) and meat (Kronberg et al., 2011), resulting in improved human health (Zachut et al., 2010). Flaxseed is also available in organically certified form in the Northeast, and has been gaining interest as a potential alternative energy source to corn for certified organic dairy farms. We recently demonstrated that whereas nutrient digestibility (DM, OM, and NDF) and methane emissions decreased, molar proportions of acetate and propionate increased by replacing orchardgrass herbage with incremental levels $(0,5,10$, or $15 \%$ of the total diet DM) of ground flaxseed in a dual-flow continuous-culture fermentor system (Soder et al., 2012). Conversely, Scholljegerdes and Kronberg (2010), supplementing ground flaxseed at $0.18 \%$ of $\mathrm{BW}$ on a DM basis to beef cattle grazing summer native rangelands on the northern Great Plains, reported no changes in ruminal NDF digestibility and molar proportion of propionate compared with the herbage-only diet or to herbage plus a corn/ soybean meal-based concentrate. Despite these recent reports (Scholljegerdes and Kronberg, 2010; Soder et al., 2012), there is still limited in vitro or in vivo scientific information regarding the effect of supplementing herbage-based diets with TMR on ruminal fermentation and bacterial N synthesis. Soder and Muller (2007) reported increased interest by graziers in incorporating a TMR into an herbage-based diet; however, little nutritional guidance was available on reformulating the TMR for optimal ruminal fermentation and animal performance. Vibart et al. (2008, 2010) reported improved ruminal fermentation (Vibart et al., 2010) and lactational performance (Vibart et al., 2008) in diets with a greater proportion of herbage than TMR. Bargo et al. (2002b) reported that supplementing herbage with TMR depressed ruminal proteolysis in lactating dairy cows grazing mixed grass species but depressed ruminal nutrient digestion was also observed. Gregorini et al. (2010) found that supplementing corn silage $9 \mathrm{~h}$ as opposed to $1 \mathrm{~h}$ before feeding an herbage diet improved $\mathrm{N}$ utilization and VFA profiles in continuous-culture fermentation.

As stated above, a handful of studies exist that compare an herbage diet with TMR, supplementing herbage with TMR, and 1 in vitro study that evaluated flaxseed supplementation of an herbage diet. However, we are not aware of studies that directly compare the effects of TMR compared with flaxseed as supplemental feed sources in herbage-based diets. Therefore, the objectives of this study were to evaluate the effects of supplementing an herbage diet with TMR or flaxseed on nutrient digestibility, fermentation profile, and bacterial $\mathrm{N}$ synthesis during continuous-culture fermentation. Compared with an all-herbage diet, we hypothesize that partially replacing herbage with TMR or ground flaxseed will increase energy capture by bacteria, thus improving both bacterial protein synthesis and overall fermentation characteristics in a dual-flow continuous-culture fermentor system.

\section{MATERIALS AND METHODS}

\section{Experimental Design and Diets}

This study was conducted at the US Department of Agriculture-Agricultural Research Service Pasture Systems and Watershed Management Research Unit (University Park, PA) from July to September 2011. Orchardgrass herbage was harvested on May 5, 2011, in the afternoon at the Russell Larson Agricultural Research Farm (Rock Springs, PA) from a pure stand with a forage plot harvester (HEGE 212; Wintersteiger AG, Waldenburg, Germany; 1.5-m-wide swath) at 10 $\mathrm{cm}$ above soil level, approximately 3 wk after the previous cutting so that herbage was in a vegetative stage of growth typical of high-quality herbage $(25$ to $30 \mathrm{~cm}$ tall). Within $30 \mathrm{~min}$ of harvest, the herbage was placed in cloth bags and frozen $\left(-4^{\circ} \mathrm{C}\right)$ until being freeze dried (Ultra 35 Super ES; Virtis Co. Inc., Gardiner, NY) and ground (Wiley mill; Thomson Scientific Inc., Philadelphia, PA; 2-mm screen). The TMR was collected on April 26, 2011, from The Pennsylvania State University (University Park) dairy barn (Table 1), freeze dried, and ground as done with herbage. The TMR consisted of a forage:concentrate ratio of 69:31 and was typical of a TMR fed in central Pennsylvania to moderateproducing dairy cows. Whole, certified organic, brown flaxseed (United Natural Foods Inc., Dayville, CT; product of Canada) was ground in small batches before each period (2-mm screen) and stored in the refrigerator before and after grinding to minimize oxidation of lipids.

Each fermentor was fed a total of $70 \mathrm{~g}$ of $\mathrm{DM} / \mathrm{d}$ of 1 of 4 diets (Table 2): (1) 100\% freeze-dried orchardgrass herbage (HERB), (2) 100\% freeze-dried TMR (100TMR), (3) 50\% orchardgrass herbage supplemented with 50\% TMR (50TMR), or (4) $90 \%$ orchardgrass herbage supplemented with $10 \%$ ground flaxseed (FLAX). We chose to supplement herbage with $50 \%$ TMR to yield a relatively similar proportion of forage:concentrate ratio between the 2 herbagesupplemented diets (50TMR and FLAX). In fact, the forage:concentrate ratios averaged 84:16 and 90:10 for 50TMR and FLAX diets, respectively. The proportion of ground flaxseed ( $10 \%$ of total diet DM) fed in the current study was chosen based on our previous experiment (Soder et al., 2012), in which no major differences 
Table 1. Ingredient composition of the TMR

\begin{tabular}{lc}
\hline Item & $\%$ of DM \\
\hline Corn silage & 52.4 \\
Alfalfa haylage & 13.4 \\
Ground corn & 11.1 \\
Canola meal & 5.00 \\
Cooked soybeans & 5.40 \\
Sugar & 4.20 \\
Cottonseed hulls & 3.80 \\
Grass hay & 2.70 \\
Urea & 0.20 \\
Vitamins/minerals & 1 \\
\hline
\end{tabular}

${ }^{1}$ The premix contained (as-is basis) $0.86 \%$ trace mineral mix, $8.0 \%$ $\mathrm{MgO}(56 \% \mathrm{Mg}), 6.4 \% \mathrm{NaCl}, 0.48 \%$ vitamin ADE premix, $37.2 \%$ limestone, $0.07 \%$ selenium premix, $46.7 \%$ dry corn distillers grains with solubles, $14.1 \% \mathrm{Ca}, 0.39 \% \mathrm{P}, 4.59 \% \mathrm{Mg}, 0.44 \% \mathrm{~K}, 0.39 \% \mathrm{~S}, 6.91 \mathrm{mg}$ of $\mathrm{Se} / \mathrm{kg}, 362 \mathrm{mg}$ of $\mathrm{Cu} / \mathrm{kg}, 1,085 \mathrm{mg}$ of $\mathrm{Zn} / \mathrm{kg}, 186 \mathrm{mg}$ of $\mathrm{Fe} / \mathrm{kg}$, $276,717 \mathrm{IU}$ of vitamin $\mathrm{A} / \mathrm{kg}, 75,000 \mathrm{IU}$ of vitamin $\mathrm{D} / \mathrm{kg}$, and 1,983 IU of vitamin $\mathrm{E} / \mathrm{kg}$.

in nutrient digestibility was observed among the control (0\% ground flaxseed) and 5- and 10-\% flaxseed diets, unlike the diet with $15 \%$ ground flaxseed, which negatively affected nutrient digestibility and overall fermentation characteristics.

For the HERB and 100TMR diets, each fermentor received herbage (HERB) or TMR (100TMR) in 4 equal feedings at $0730,1030,1400$, and $1900 \mathrm{~h}$. For the 50 TMR diet, fermentors were fed TMR at 0730 and 1400 $\mathrm{h}$ and fed herbage at 1030 and $1900 \mathrm{~h}$. For the FLAX diet, the herbage portion of the diet was also equally divided in 4 feedings daily, whereas the grain/flaxseed portion was fed twice daily in equal amounts at 0730 and $1400 \mathrm{~h}$ to mimic supplementation strategies often used in grazing dairy herds where supplement is pro- vided during milking time. The study was conducted as a $4 \times 4$ Latin square design, with each dual-flow continuous-culture fermentation unit receiving each diet once over the 4 periods. Each of the four 10-d periods consisted of $7 \mathrm{~d}$ for diet adaptation and $3 \mathrm{~d}$ for sample collection.

Although it is recognized that the TMR used in this experiment was formulated for a confinement herd, it is not uncommon in the Northeast for grazing herds to simply feed the winter ration in lower quantities during the grazing season, which may result in imbalances in nutrient intake, particularly $\mathrm{CP}$, when herbage is included in the ration (Soder and Muller, 2007). A more progressive approach is to reformulate the TMR during the grazing season, most frequently by substituting fresh herbage DM for haylage/silages (usually on a 1:1 basis) or decreasing the protein sources (particularly RDP supplements; Soder and Muller, 2007). In the current study, simple substitutions for fresh herbage (TMR or flaxseed) were used to represent what commonly would occur on grazing dairy farms.

\section{Continuous-Culture Operation}

For this study, a 4-unit dual-flow continuous-culture fermentor system (Omni-Culture Plus; Virtis Co. Inc.), similar to that described by Hoover et al. (1989), was used with the following modifications: $\mathrm{pH}$ was not controlled, diets were not pelleted, fermentor volumes ranged from 1,100 to $1,140 \mathrm{~mL}$, and urea was added to the mineral buffer solution at a rate of $0.4 \mathrm{~g} / \mathrm{L}$ to simulate recycled N (Weller and Pilgrim, 1974). Ruminal fluid and digesta were collected from a ruminally

Table 2. Chemical composition (\% of DM, unless otherwise stated) of the ground flaxseed ingredient, and diets containing 100\% herbage (HERB), 100\% TMR (100TMR), 50\% HERB:50\% TMR (50TMR), or herbagebased plus $10 \%$ ground flaxseed (FLAX) administered to a dual-flow continuous-culture fermentor system

\begin{tabular}{|c|c|c|c|c|c|}
\hline \multirow[b]{2}{*}{ Item $^{1}$} & \multirow{2}{*}{$\begin{array}{c}\text { Ingredient } \\
\text { Flaxseed }\end{array}$} & \multicolumn{4}{|c|}{$\operatorname{Diet}^{2}$} \\
\hline & & HERB & 100TMR & 50TMR & FLAX \\
\hline $\mathrm{OM}$ & 91.8 & 93.6 & 89.7 & 91.7 & 93.9 \\
\hline $\mathrm{CP}$ & 20.5 & 25.9 & 16.1 & 21.0 & 25.4 \\
\hline $\mathrm{RDP}, \%$ of $\mathrm{CP}$ & 63.0 & 79.0 & 77.0 & 78.2 & 77.4 \\
\hline $\mathrm{NDF}$ & 33.9 & 49.3 & 44.8 & 47.1 & 47.8 \\
\hline WSC & 4.70 & 12.2 & 7.1 & 9.7 & 11.5 \\
\hline Starch & 0.10 & 1.4 & 13.8 & 7.6 & 1.3 \\
\hline NSC & 4.80 & 13.6 & 20.9 & 17.3 & 12.8 \\
\hline $\mathrm{NE}_{\mathrm{L}},{ }^{3} \mathrm{Mcal} / \mathrm{kg}$ & 3.23 & 1.41 & 1.56 & 1.49 & 1.59 \\
\hline $\mathrm{Ca}$ & 0.31 & 0.44 & 1.19 & 0.82 & 0.42 \\
\hline $\mathrm{P}$ & 0.64 & 0.35 & 0.50 & 0.43 & 0.39 \\
\hline $\mathrm{Mg}$ & 0.38 & 0.29 & 0.35 & 0.32 & 0.30 \\
\hline $\mathrm{K}$ & 0.90 & 2.38 & 1.95 & 2.17 & 2.23 \\
\hline $\mathrm{Na}$ & 0.03 & 0.22 & 0.11 & 0.16 & 0.20 \\
\hline
\end{tabular}

${ }^{1} \mathrm{WSC}=$ water-soluble carbohydrate; NSC $=\mathrm{WSC}+$ starch.

${ }^{2}$ Calculated using the actual nutrient composition and proportion of individual ingredients.

${ }^{3}$ Estimated by the NRC (2001) model. 
fistulated, lactating, multiparous Holstein cow cared for in accordance with the Pennsylvania State University Animal Care and Use (IACUC no. 31240) guidelines. The donor cow received the same TMR (ad libitum) that was used in the experiment. The donor cow was housed in a freestall barn with access to a concrete, outdoor lot at the Pennsylvania State University dairy farm (University Park). Approximately $3 \mathrm{~h}$ after feeding, the donor cow was moved to a small holding pen and $6 \mathrm{~L}$ of ruminal fluid was collected with a hand pump into a prewarmed insulated vessel. Approximately 600 $\mathrm{g}$ of solid digesta representing the ventral, dorsal, and central areas of the rumen were collected and placed in a separate prewarmed insulated container. Within 15 min of collection, the fluid was strained through 4 layers of cheesecloth and poured into each of the prewarmed fermentation jars until it cleared the overflow spout. Solid digesta was mixed thoroughly by hand and $25 \mathrm{~g}$ was added to each fermentor.

The units received $\mathrm{CO}_{2}$ gas continually (to maintain anaerobiosis) at a rate of $20 \mathrm{~mL} / \mathrm{min}$ and the temperature was maintained at $39^{\circ} \mathrm{C}$. Fermentor contents were continuously stirred by a central propeller apparatus driven by magnets at the rate of $255 \mathrm{rpm}$. Solid mean retention time, solid dilution rate, and liquid dilution rate of fermentors were $24 \mathrm{~h}, 4 \% / \mathrm{h}$, and $11 \% / \mathrm{h}$, respectively, by regulation of the buffer input and filtrate removal (Bargo et al., 2003). Fermentor pH was recorded immediately before each of the 4 daily feedings.

Liquid and solid overflow were collected in 4-L plastic containers. During the 7-d adaptation period, the overflow containers were weighed once daily and the contents discarded. After being emptied on d 7, the containers were immersed halfway in a chilled $\left(4^{\circ} \mathrm{C}\right)$ water bath and each received $20 \mathrm{~mL}$ of $50 \% \mathrm{H}_{2} \mathrm{SO}_{4}$ to halt microbial action and growth. During the last $3 \mathrm{~d}$ of each period, the liquid and solid overflow from each fermentor were combined and mixed in a blender (Waring Products, New Hartford, CT) for 30 s. After mixing, a $100-\mathrm{mL}$ sample for overflow DM determination was taken and composited over the $3 \mathrm{~d}$. For determination of VFA (via gas chromatography; Rumen Fermentation Profiling Laboratory, West Virginia University, Morgantown) and $\mathrm{NH}_{3}-\mathrm{N}$ (Yang and Varga, 1989), a 50-mL sample was strained through 8 layers of cheesecloth before $15-\mathrm{mL}$ samples were placed in $30-\mathrm{mL}$ plastic bottles. An additional 1-L sample was composited over the 3-d sample period, later freeze dried, and passed through a $1-\mathrm{mm}$ sieve and stored in a sealed plastic bag for later analyses of DM, OM, NDF, CP, and total purines. On d 10, in addition to the aforementioned sampling, the contents of each fermentor jar were processed per the methods of Griswold et al. (1996) for bacterial isolation with the following modification: in place of the initial centrifugation, contents were mixed gently in the blender for $30 \mathrm{~s}$ and strained through 2 layers of a $53-\mu \mathrm{m}$ Nitex fabric (Wildco, Buffalo, NY) into a 2-L plastic container with $5 \mathrm{~mL}$ of $50 \% \mathrm{H}_{2} \mathrm{SO}_{4}$ added to stop microbial growth. Contents were then centrifuged 3 times at $20,000 \times g$ for $20 \mathrm{~min}$, with the pellet resuspended in $0.9 \%$ saline and $50 \%$ methanol, respectively, for the last 2 centrifugations (Griswold et al., 1996). The final pellet was placed in a plastic container and stored in the freezer until lyophilization.

\section{Nutrient Analyses}

Samples of the orchardgrass, TMR, and ground flaxseed were analyzed by wet chemistry (DairyOne Laboratories, Ithaca, NY) according to the following methods: DM (method 930.15; AOAC International, 2006), CP (method 990.03; AOAC International, 2006), NDF (Ankom Technology method 6: NDF in feeds - filter bag technique for A200; solutions as in Van Soest et al., 1991), water-soluble carbohydrates (WSC) (Hall et al., 1999), starch (application note number 319; YSI Inc. Life Sciences, Yellow Springs, Ohio), and minerals (Ca, P, Mg, K, and Na; Thermo IRIS Advantage HX or Intrepid Inductively Coupled Plasma Radial Spectrometer after microwave digestion; CEM application note for acid digestion; CEM Corp., Matthews, NC). The RDP was determined using the procedures of Coblentz et al. (1999) using Cornell Streptomyces griseus enzymatic digestion. The NSC concentration was calculated by adding WSC plus starch. Effluent samples were analyzed for DM and OM (methods 930.15 and 942.05; AOAC International, 2006, respectively) and CP content (micro-Kjeldahl digestion using $75-\mathrm{mL}$ calibrated tubes with $\mathrm{CuSO}_{4} / \mathrm{K}_{2} \mathrm{SO}_{4}$ catalyst; method 976.06; AOAC International, 2006). The NDF content of the effluent was determined by the methods of Van Soest et al. (1991) with amylase and sodium sulfite used in the NDF procedure (inclusive of ash). Concentrations of total purines (Zinn and Owens, 1986) in effluent and isolated bacterial pellets were used to partition effluent $\mathrm{N}$ flow into bacterial and nonbacterial fractions and to calculate true DM and OM digestibilities and flows.

\section{Statistical Analysis and Calculations}

Data were analyzed as a $4 \times 4$ Latin square design using PROC GLM of SAS (SAS Institute Inc., Cary, NC). The model included the fixed effects of diet and period, the random effect of fermentor, and the residual error. Preplanned, single degree of freedom orthogonal contrasts were constructed to assess the effects of (1) feeding system (herbage vs. confinement; HERB vs. 100TMR), (2) herbage supplementation (HERB 
vs. 50TMR + FLAX), and (3) herbage supplemental source (50TMR vs. FLAX). Least squares means and standard error of the mean are reported for all data. Significance was declared at $P<0.05$ and trends at $0.05<P<0.10$.

Apparent (DM, OM, and CP) and true (DM, OM, and NDF) digestibilities of nutrients were calculated as follows (using DM as an example):

DM apparently digested (expressed as \% of total DM)

$$
=[(\mathrm{g} \text { of DMI }-\mathrm{g} \text { of effluent flow DM })
$$

$$
\div \mathrm{g} \text { of } \mathrm{DMI}] \times 100
$$

with effluent corrected for grams of buffer DM;

DM truly digested (expressed as a $\%$ of total DM) $=$ $\{[\mathrm{g}$ of DMI - (g of effluent flow DM $-\mathrm{g}$ of bacterial DM) $] \div \mathrm{g}$ of $\mathrm{DMI}\} \times 100$,

with effluent corrected for grams of buffer DM.

Nitrogen flows $(\mathrm{mg} / \mathrm{d})$ were calculated as follows:

$$
\begin{aligned}
& \mathrm{NH}_{3}-\mathrm{N} \text { flow }=\left[\left(\text { effluent } \mathrm{NH}_{3}-\mathrm{N}(\mathrm{mg} \%)\right.\right. \\
& \times(\mathrm{mg} \text { of total effluent flow } / 100)] ;
\end{aligned}
$$

NAN flow $=($ mg of total effluent $\mathrm{N})$

- (mg of effluent $\left.\mathrm{NH}_{3}-\mathrm{N}\right)$;

Bacterial-N flow $=(\mathrm{mg}$ of effluent bacterial DM $)$

$\times(\% \mathrm{~N}$ in microbes $)$;

$$
\begin{gathered}
\text { Dietary-N flow }=(\mathrm{mg} \text { of effluent NAN }) \\
-(\mathrm{mg} \text { of effluent bacterial } \mathrm{N}) .
\end{gathered}
$$

\section{RESULTS AND DISCUSSION}

Compared with the 100TMR diet, apparent digestibilities of DM and OM did not differ, whereas NDF digestibility was higher $(+10 \%$ units; $P<0.001)$ for the HERB diet (Table 3), which may be explained by the relatively high quality $(\mathrm{CP}=25.9 \%$ and $\mathrm{NDF}=49.3 \%$; Table 2) herbage used in the current experiment. Mean and minimum fermentor $\mathrm{pH}$ were also higher $(P<$ 0.05 ) for the HERB diet compared with the 100TMR diet (Table 3). It must be noted that the change in $\mathrm{pH}$ was mild; therefore, minimal effect on ruminal fermentation might be expected. Although comparisons of herbage and TMR are very limited, Vibart et al. (2010) reported no differences in NDF digestibility as annual ryegrass (Lolium multiflorum) herbage replaced TMR up to $45 \%$ of the diet DM in continuous-culture fermentation. Bargo et al. (2002b) found that inclusion of TMR at a rate of $70 \%$ of total DMI in an herbage diet reduced the total potentially degradable fraction of DM and the potentially digested fraction of herbage NDF. However, a 100\% TMR diet was not fed in either of these 2 previous studies, which may explain the variant responses in nutrient digestibilities compared with the current study.

Although true digestibility of DM was not affected by feeding strategy (HERB vs. 100TMR), herbage supplementation (HERB vs. 50TMR + FLAX), or source of supplement (50TMR vs. FLAX), true OM

\begin{tabular}{|c|c|c|c|c|c|c|c|c|}
\hline \multirow[b]{2}{*}{ Item } & \multicolumn{4}{|c|}{$\operatorname{Diet}^{1}$} & \multirow[b]{2}{*}{ SEM } & \multicolumn{3}{|c|}{ Contrast,${ }^{2} P$-value } \\
\hline & HERB & 100TMR & 50TMR & FLAX & & $\begin{array}{l}\text { HERB vs. } \\
\text { 100TMR }\end{array}$ & $\begin{array}{l}\text { HERB vs. } \\
\text { supplement }\end{array}$ & $\begin{array}{l}\text { FLAX vs. } \\
50 \text { TMR }\end{array}$ \\
\hline \multicolumn{9}{|c|}{ Apparent digestibility } \\
\hline $\mathrm{DM}, \%$ & 64.3 & 60.0 & 58.0 & 57.8 & 1.25 & 0.22 & 0.054 & 0.090 \\
\hline OM, \% & 70.0 & 64.8 & 62.8 & 63.2 & 1.30 & 0.16 & 0.048 & 0.91 \\
\hline NDF, \% & 84.9 & 74.9 & 78.1 & 83.7 & 0.88 & $<0.001$ & 0.010 & 0.004 \\
\hline $\mathrm{OM}, \%$ & 84.2 & 78.2 & 80.2 & 80.5 & 1.70 & 0.047 & 0.11 & 0.90 \\
\hline \multicolumn{9}{|l|}{$\mathrm{pH}$} \\
\hline Mean & 6.62 & 6.37 & 6.49 & 6.65 & 0.043 & 0.005 & 0.34 & 0.036 \\
\hline Minimum & 6.34 & 6.03 & 6.22 & 6.34 & 0.018 & $<0.001$ & 0.26 & 0.003 \\
\hline Maximum & 6.90 & 6.70 & 6.78 & 6.94 & 0.075 & 0.11 & 0.69 & 0.19 \\
\hline
\end{tabular}
digestibility was higher by $6 \%$ units $(P=0.047)$ in the HERB compared with the 100TMR diet. An herbageonly diet composed of perennial ryegrass (Lolium pe-

Table 3. Nutrient digestibility and pH of diets containing 100\% herbage (HERB), 100\% TMR (100TMR), 50\% HERB:50\% TMR (50TMR), or herbage-based plus $10 \%$ ground flaxseed (FLAX) administered to a dual-flow continuous-culture fermentor system

${ }^{1} \mathrm{n}=4$ observations per diet.

${ }^{2}$ Orthogonal contrasts for effects of feeding system (HERB vs. 100TMR), herbage supplementation (HERB vs. 50TMR + FLAX), and herbage supplemental source (50TMR vs. FLAX). 
Table 4. Volatile fatty acid production of diets containing 100\% herbage (HERB), 100\% TMR (100TMR), 50\% HERB:50\% TMR (50TMR), or herbage-based plus $10 \%$ ground flaxseed (FLAX) administered to a dual-flow continuous-culture fermentor system

\begin{tabular}{|c|c|c|c|c|c|c|c|c|}
\hline \multirow[b]{2}{*}{ Item } & \multicolumn{4}{|c|}{ Diet $^{1}$} & \multirow[b]{2}{*}{ SEM } & \multicolumn{3}{|c|}{ Contrast, ${ }^{2} P$-value } \\
\hline & HERB & 100TMR & 50TMR & FLAX & & $\begin{array}{l}\text { HERB vs. } \\
100 \mathrm{TMR}\end{array}$ & $\begin{array}{l}\text { HERB vs. } \\
\text { supplement }\end{array}$ & $\begin{array}{l}\text { FLAX vs. } \\
50 \mathrm{TMR}\end{array}$ \\
\hline $\begin{array}{l}\text { Total VFA, mmol/L } \\
\mathrm{mol} / 100 \mathrm{~mol}\end{array}$ & 60.0 & 76.6 & 76.3 & 60.9 & 0.888 & $<0.001$ & $<0.001$ & $<0.001$ \\
\hline Acetate (A) & 34.1 & 50.3 & 50.0 & 36.2 & 0.930 & $<0.001$ & $<0.001$ & $<0.001$ \\
\hline Propionate $(\mathrm{P})$ & 14.0 & 16.5 & 16.4 & 13.8 & 0.409 & 0.004 & 0.061 & 0.004 \\
\hline Valerate & 1.95 & 1.80 & 1.68 & 1.92 & 0.149 & 0.50 & 0.43 & 0.30 \\
\hline Isovalerate & 0.22 & 0.44 & 0.36 & 0.25 & 0.047 & 0.016 & 0.18 & 0.13 \\
\hline $\mathrm{A}: \mathrm{P}$ & 2.44 & 3.04 & 3.05 & 2.65 & 0.110 & 0.009 & 0.024 & 0.042 \\
\hline$(A+B): P$ & 3.11 & 3.47 & 3.49 & 3.25 & 0.113 & 0.068 & 0.11 & 0.18 \\
\hline
\end{tabular}

${ }_{\mathrm{n}}=4$ observations per diet.

${ }^{2}$ Orthogonal contrasts for effects of feeding system (HERB vs. 100TMR), herbage supplementation (HERB vs. 50TMR + FLAX), and herbage supplemental source (50TMR vs. FLAX).

renne L.) with $\mathrm{CP}$ and NDF concentrations (24.1 and $46.5 \%$, respectively) similar to those of the herbage used herein also led to enhanced in vitro OM digestibility compared with a TMR diet in an experiment using spring-calving Holstein-Friesian cows (O'Neill et al., 2011). Vibart et al. (2010) reported that as TMR was replaced by annual ryegrass herbage, in vitro true OM disappearance increased. Those authors (Vibart et al., 2010) suggested that this was due to the high-quality herbage used, which may have provided a better balance of nutrients to support improved OM digestibility, corroborating present results.

Concentrations of total VFA and molar proportions of individual VFA were well within the reported ranges from other continuous-culture studies (Bargo et al., 2002b, 2003; Vibart et al., 2010; Soder et al., $2012)$. Concentration of total VFA $(P<0.001)$, the molar proportions of acetate $(P<0.001)$, propionate $(P=0.004)$, and isovalerate $(P=0.016)$, as well as the acetate:propionate $(\mathbf{A}: \mathbf{P})$ ratio $(P=0.009)$ were all higher in fermentors fed 100TMR compared with HERB, whereas the acetate + butyrate:propionate ratio tended $(P=0.068)$ to be higher for the former compared with the latter treatment (Table 4). On the other hand, the molar proportion of butyrate was reduced $(P$ $<0.001$ ) with feeding 100TMR compared with HERB. Vibart et al. (2010) also reported increased acetate and propionate and decreased butyrate in diets with a higher proportion of TMR than herbage; however, in contrast to the current study, the ratio of acetate + butyrate:propionate increased as the proportion of herbage increased (Vibart et al., 2010). This is likely explained by the greater variation in butyrate $(40 \%$ decrease) between the 100\% TMR diet and the diet containing 55\% TMR:45\% herbage in the Vibart et al. (2010) experiment compared with the smaller varia- tion (24\% decrease in butyrate between HERB and 100TMR) in the current study. Additionally, Vibart et al. (2010) were not comparing 100\% TMR with $100 \%$ herbage diets, as was done in the current study.

Compared with the HERB diet, the 100TMR diet had noticeably higher concentrations of starch and WSC (Table 2), which may have increased the supply of fermentable energy in the culture system, resulting in superior production of total VFA (Table 4). Because NDF digestibility was reduced with feeding the 100TMR compared with the HERB diet, it can be hypothesized that the rate of fermentation of NSC and starch was high enough to counterbalance the depression in NDF digestibility, yielding a total concentration of VFA that was significantly higher in the former compared with the latter diet. Bargo et al. (2003) also observed higher $(P<0.05)$ concentrations of total and individual VFA when feeding continuous-culture fermentors an herbage plus concentrate diet rather than an herbage-only diet. Replacing perennial ryegrass herbage with incremental levels $(0,15,30$, or $45 \%$ diet DM) of a barley/steamflaked corn grain mixture during continuous-culture fermentation resulted in linear increases in the apparent digestibilities of DM, OM, and NSC, but linear decreases in the apparent digestibility of NDF and total concentration of VFA (Wales et al., 2009), suggesting that depressed fiber digestibility was the major reason for reduced VFA production. Although Wales et al. (2009) data contradicts results reported herein, it must be noted that their concentrate supplementation level was much higher (and of a different source) than in the current study. Vibart et al. (2010) observed linear increases in the true digestibility of DM and concentration of total VFA that were accompanied by a lack of diet effect on NDF digestibility when TMR was replaced by incremental levels of herbage, suggesting that DM 
digestion was the driving force regulating VFA production. However, because we are not aware of existing data using treatments similar to those presented here, the cited studies provide the closest data that can be obtained for comparisons.

The higher $(P=0.009)$ A:P ratio with feeding the 100TMR diet compared with the HERB diet was a result of increased $(P<0.001)$ molar proportions of acetate in the former rather than the latter diet (Table 4). It is well known that ruminal acetate is derived primarily from the fermentation of plant structural carbohydrates in the rumen. Compared with the herbage-only diet (HERB), the 100TMR diet had numerically lower NDF concentration (49.3 and $44.8 \%$ for the HERB and 100TMR diets, respectively) and significantly lower apparent NDF digestibility (84.9 and $74.9 \%$ for the HERB and 100TMR diets, respectively), which are expected to result in reduced, not increased, acetate production. However, the TMR was high in forage (69:31 forage:concentrate ratio; Table 1) and NDF digestibility, which, combined with a high fermentation rate from concentrate, possibly explains the superior molar proportion of acetate. Additionally, the production of total VFA was $22 \%$ higher in the 100TMR diet compared with the HERB diet, which promoted greater acetate production independent of diet NDF concentration and NDF digestibility.

Feeding system (HERB vs. 100TMR) had minor effect on $\mathrm{N}$ metabolism in the present study (Table 5). The concentration of $\mathrm{NH}_{3}-\mathrm{N}(P=0.066)$ and flow of $\mathrm{NH}_{3}-\mathrm{N}(P=0.074)$ tended to be higher, whereas flows of total N $(P=0.002)$ and NAN $(P=0.037)$ increased with feeding HERB compared with the 100TMR diet as a result of a 9.8-percentage-unit increase in dietary $\mathrm{CP}$ (Table 2) comparing the former with the latter diet. Increased dietary $\mathrm{CP}$ also explains the higher $(P$
$=0.048)$ total $\mathrm{N}$ flow between the FLAX and 50TMR diets (Table 5). It was somewhat surprising to find that a $35 \%$ increase in the concentration of NSC with feeding 100TMR compared with HERB did not elicit a significant response in bacterial $\mathrm{N}$ flow. For instance, increasing NSC concentration by $59 \%$ with feeding high- compared with low-NSC fresh alfalfa during continuous culture (Berthiaume et al., 2010) or by $18 \%$ with feeding high- compared with low-NSC alfalfa baleage to late-lactation dairy cows (Brito et al., 2009) significantly increased bacterial protein synthesis by 12.5 and $6 \%$, respectively. Bargo et al. (2003) reported that a linear increase in bacterial $\mathrm{N}$ flow coincided with enhanced herbage DMI and NSC during continuousculture fermentation. Clark et al. (1992) reported a positive relationship between $\mathrm{OM}$ intake and passage of bacterial $\mathrm{N}$ to the small intestine using a data set from over 36 experiments conducted with duodenally cannulated cows. Likewise, Oldick et al. (1999) showed that regression equations containing the independent variables DMI and dietary concentration of NDF were the best predictors of duodenal flow of bacterial $\mathrm{N}$ when a data set including 213 treatment means from 55 published studies were used in the analysis. Thus, enhanced bacterial N flow observed previously (Bargo et al., 2003; Brito et al., 2009) can be explained by a combination of increased DMI and (or) supply of fermentable energy through NSC. Higher $(P=0.047)$ true OM digestibility (Table 3) with feeding HERB compared with 100TMR may have counteracted the $35 \%$ unit difference in NSC concentration between these 2 diets leading to similar bacterial $\mathrm{N}$ flow.

Herbage supplementation (HERB vs. 50TMR + FLAX diet contrast) reduced the apparent digestibilities of DM $(P=0.054), \mathrm{OM}(P=0.048)$, and $\mathrm{NDF}(P$ $=0.01$; Table 3$)$. Replacing high-quality, highly digest-

Table 5. Nitrogen metabolism of diets containing 100\% herbage (HERB), 100\% TMR (100TMR), 50\% HERB:50\% TMR (50TMR), or herbagebased plus $10 \%$ ground flaxseed (FLAX) administered to a dual-flow continuous-culture fermentor system

\begin{tabular}{|c|c|c|c|c|c|c|c|c|}
\hline Item & \multicolumn{4}{|c|}{ Diet $^{1}$} & SEM & \multicolumn{3}{|c|}{ Contrast, ${ }^{2} P$-value } \\
\hline $\mathrm{CP}$ digestibility, $\%$ & 84.2 & 82.1 & 84.9 & 81.6 & 2.36 & 0.537 & 0.744 & 0.365 \\
\hline \multicolumn{9}{|l|}{$\mathrm{N}$ flow, $\mathrm{g} / \mathrm{d}$} \\
\hline Total N & 1.73 & 1.21 & 1.63 & 1.87 & 0.067 & 0.002 & 0.796 & 0.048 \\
\hline Dietary N & 0.39 & 0.28 & 0.30 & 0.45 & 0.053 & 1.179 & 0.817 & 0.106 \\
\hline \multicolumn{9}{|l|}{ Bacterial efficiency } \\
\hline $\mathrm{mg}$ of bacterial $\mathrm{N} / \mathrm{kg}$ of $\mathrm{OM}$ truly digested & 16.1 & 14.7 & 18.5 & 14.9 & 1.46 & 0.517 & 0.291 & 0.769 \\
\hline
\end{tabular}

${ }^{1} \mathrm{n}=4$ observations per diet.

${ }^{2}$ Orthogonal contrasts for effects of feeding system (HERB vs. 100TMR), herbage supplementation (HERB vs. 50TMR + FLAX), and herbage supplemental source (50TMR vs. FLAX). 
ible herbage with forage TMR (i.e., corn silage, alfalfa haylage, and grass hay; Table 1) possibly explains these observed reductions in nutrient digestibilities. Whereas the NDF digestibilities of HERB and FLAX diets were relatively similar ( 84.9 and $83.7 \%$, respectively), feeding the 50TMR diet depressed $(P=0.04$; Table 3) NDF digestibility compared with the FLAX diet. Therefore, differences in fiber digestibility between herbage and TMR forage ingredients appear to be the major contributors to reduced apparent digestibilities of DM, OM, and NDF, particularly when TMR was the supplemental source. The diurnal variation in fermentor $\mathrm{pH}$ in the current study was too small (ranging from 0.56 to $0.67 \mathrm{pH}$ units) to explain the depressed nutrient digestibility with herbage supplementation. In fact, larger diurnal variation in ruminal $\mathrm{pH}(>1.0 \mathrm{pH}$ unit) resulted in depressed fiber digestibilities in confined (Brito and Broderick, 2006) and grazing (Bargo et al., 2002b) Holstein cows.

Herbage supplementation (HERB vs. 50TMR + FLAX contrast) increased the total concentration of VFA $(P<0.001)$, the molar proportion of acetate $(P<$ $0.001)$, and the A:P ratio $(P=0.024)$, whereas the molar proportion of propionate tended $(P=0.061)$ to increase and that of butyrate decreased $(P<0.001$; Table 4). It is important to note, however, that the observed increases in the total VFA concentration, acetate proportion, and A:P ratio were primarily driven by TMR supplementation (50TMR diet), which yielded higher $(P<0.05)$ values for these 3 variables compared with the FLAX diet. Conversely, the 50TMR diet resulted in a lower $(P=0.011)$ molar proportion of butyrate compared with the FLAX diet, thus explaining the decline $(P<0.001)$ in butyrate proportion with herbage supplementation (i.e., HERB vs. 50TMR + FLAX).

We showed in our previous study that replacing orchardgrass herbage with incremental dietary levels of ground flaxseed linearly decreased the molar proportion of butyrate during continuous-culture fermentation (Soder et al., 2012). Likewise, the molar proportion of butyrate was reduced with herbage supplementation, particularly TMR in the current study (Table 4). Recently, Vibart et al. (2010) observed a linear decrease in the molar proportion of butyrate when TMR rather than herbage was the major dietary component, which corroborates our current and previous (Soder et al., 2012 ) results. The concentration of ruminal butyrate is also known to decrease with increasing concentrate supplementation (Mirzaei-Aghsaghali and Maheri-Sis, 2011). In fact, a lower $(P=0.011)$ molar proportion of butyrate was observed when the amount of concentrate increased from $10 \%$ (FLAX diet) to $16 \%$ (50TMR diet; Table 4). Furthermore, enhanced fiber intake showed increases in the Butyrivibrio genus population (Mrázek et al., 2006) in cows, as well as in the Butyrivibrio fibrisolvens and Fibrobacter succinogenes species (Fernando et al., 2010) in beef steers, whereas high-energy intake suppressed these bacterial populations in the rumen.

Flaxseed has been shown to depress OM and fiber digestibilities in dairy cows as previously reported (Ben Salem et al., 1993; Martin et al., 2008). However, these depressions in nutrient digestibilities were more pronounced when flaxseed was fed with corn silage- than with hay-based diets, suggesting that an interaction may exist between the ingredient composition of the basal diet and the increased source of dietary fat (e.g., flaxseed) to regulate the overall effects of flaxseed on nutrient digestibility (Petit, 2010). For instance, Fieser and Vanzant (2004) reported a supplement type $\times$ forage maturity interaction with a greater depression in apparent total-tract OM digestibility in beef steers when corn was supplemented to high-quality forages. Because we used a high-quality herbage source $(\mathrm{CP}=$ $25.9 \%$; $\mathrm{NDF}=49.3 \%$ ), the depression in apparent DM and OM digestibilities observed with feeding the FLAX diet compared with the HERB counterpart may have been primarily caused by replacing fiber from herbage with fiber from flaxseed. This is corroborated by Scholljegerdes and Kronberg (2010) who observed the lowest apparent total-tract OM digestibility when steers fed ground flaxseed grazed forage with superior nutritional quality.

In a previous study, we observed linear reductions in apparent digestibilities of nutrients (DM, OM, and NDF) when herbage was replaced by incremental dietary levels of ground flaxseed (Soder et al., 2012). In the present experiment, herbage supplementation (HERB vs. 50TMR + FLAX) also depressed nutrient digestibility as discussed in detail earlier. Although NDF digestibility averaged $83.7 \%$ with feeding the FLAX diet, NDF digestibility averaged $73.6 \%$ when a similar diet was used in our earlier experiment (Soder et al., 2012). This discrepancy in the proportion of digestible NDF is possibly related to the differences in the nutritional quality of the orchardgrass herbage used in our 2 studies. The herbage used herein had higher $\mathrm{CP}$ $(+6.0 \%$ units $)$ and lower NDF ( $-2.4 \%$ units) concentrations than that used previously (Soder et al., 2012). In addition to differences in the concentrations of $\mathrm{CP}$ and NDF, RDP concentration (\% of diet CP) was 19.5\% units higher in the current study compared with our previous results. It is well documented that supplying $\mathrm{RDP}$ as free AA, peptides, or soluble proteins increases bacterial growth, fiber digestion, or both (Argyle and Baldwin, 1989; Griswold et al., 1996; Atasoglu et al., 1999; Carro and Miller, 1999). Thus, increased RDP supply may at least partially account for discrepancies in NDF digestibilities across our 2 experiments. 
Replacing herbage with incremental dietary levels of ground flaxseed did not affect bacterial $\mathrm{N}$ flow during continuous culture (Soder et al., 2012), which corroborates results from the current study. Our 2 in vitro studies agree with Scholljegerdes and Kronberg (2010) who reported no significant differences in the duodenal flows of total $\mathrm{N}$, bacterial $\mathrm{N}$, and nonbacterial NAN when beef cattle grazed native herbage with or without corn/soybean meal- or ground flaxseed-based supplements. Although bacterial N flow averaged $750 \mathrm{mg} / \mathrm{d}$ when supplementing herbage with flaxseed (FLAX diet; Table 5), it averaged only $560 \mathrm{mg} / \mathrm{d}$ in our earlier experiment (Soder et al., 2012). This $25 \%$ difference in bacterial $\mathrm{N}$ flow between similar diets across our 2 studies possibly results from higher RDP supply as free AA, peptides, or soluble proteins in the current study compared with the previous experiment (Soder et al., 2012). For instance, compared with urea, which yields $\mathrm{NH}_{3}-\mathrm{N}$ as the sole RDP source, omasal flow of bacterial $\mathrm{N}$ averaged $14 \%$ higher $(P=0.02)$ in lactating dairy cows fed soybean meal, cottonseed meal, or canola meal, which yield preformed AA and peptides as the major RDP sources (Brito et al., 2007).

\section{CONCLUSIONS}

Compared with an herbage-only diet (HERB), feeding TMR (100TMR diet) significantly reduced the apparent digestibility of NDF, which may be explained by the high-quality herbage fed. Concentration of total VFA, the molar proportions of acetate, propionate, and isovalerate, as well as the A:P ratio were all significantly higher in fermentors fed 100TMR compared with HERB, likely in response to the enhanced supply of fermentable energy. Herbage supplementation reduced apparent digestibilities of DM, OM, and NDF in a $\mathrm{pH}$-independent manner. Therefore, it appears that replacing high-quality, highly digestible fresh herbage with TMR may have caused the observed depressions in nutrient digestibilities. Herbage supplementation significantly increased the total concentration of VFA, the molar proportion of acetate, and the A:P ratio, whereas the molar proportion of propionate tended to increase and that of butyrate significantly decreased. These changes in the culture fermentation profile were primarily driven by TMR supplementation (50TMR diet), which yielded significantly higher or lower values compared with the FLAX diet. Compared with the 50TMR diet, flaxseed provided a more stable fermentor environment (higher NDF digestibility) but poorer VFA production, with the exception of butyrate. Overall, animal performance would depend on the offset between reduced VFA production and increased fiber digestibility as a result of herbage supplementation with
TMR or flaxseed. In general, feeding system, herbage supplementation, and type of supplementation had minor effects on $\mathrm{N}$ metabolism in the present study. The few significant changes (e.g., flows of total N and NAN) were primarily linked to increased fermentor $\mathrm{N}$ supply with feeding HERB and FLAX diets. Supplementing herbage with flaxseed during the grazing season shows promise as an alternative supplement for herbage-based diets; however, further in vivo evaluation is needed to determine the optimal level that maximizes animal production and minimizes feed costs in grazing dairy cows.

\section{ACKNOWLEDGMENTS}

The authors thank J. Everhart and R. Stout (US Department of Agriculture-Agricultural Research Service, University Park, PA) for laboratory expertise and time contributed to conducting this experiment as well as L. Ruth, J. Letham, A. Waite, N. Houck, T. Edwards, and V. Ishler (Penn State University, University Park) for assistance in conducting this trial.

\section{REFERENCES}

Ambrose, D. J., J. P. Kastelic, R. Corbett, P. A. Pitney, H. V. Petit, J. A. Small, and P. Zalkovic. 2006. Lower pregnancy losses in lactating dairy cows fed a diet enriched in alpha-linolenic acid. J. Dairy Sci. 89:3066-3074.

AOAC International. 2006. Official Methods of Analyses. 18th ed. AOAC International, Gaithersburg, MD.

Argyle, J. L., and R. L. Baldwin. 1989. Effects of amino acids and peptides on rumen microbial yields. J. Dairy Sci. 72:2017-2027.

Atasoglu, C., C. Valdés, C. J. Newbold, and R. J. Wallace. 1999. Influence of peptides and amino acids on fermentation rate and de novo synthesis of amino acids by mixed micro-organisms from the sheep rumen. Br. J. Nutr. 81:307-314.

Bargo, F., L. D. Muller, J. E. Delahoy, and T. W. Cassidy. 2002a. Performance of high-producing dairy cows with three different feeding systems combining pasture and total mixed rations. J. Dairy Sci. 85:2948-2963.

Bargo, F., L. D. Muller, G. A. Varga, J. E. Delahoy, and T. W. Cassidy. 2002b. Ruminal digestion and fermentation of high-producing dairy cows with three different feeding systems combining pasture and total mixed rations. J. Dairy Sci. 85:2964-2973.

Bargo, F., G. A. Varga, L. D. Muller, and E. S. Kolver. 2003. Pasture intake and substitution rate effects on nutrient digestion and nitrogen metabolism during continuous culture fermentation. J. Dairy Sci. 86:1330-1340.

Ben Salem, H., R. Krzeminski, A. Ferlay, and M. Doreau. 1993. Effect of lipid supply in in vivo digestion in cows: Comparison of hay and corn-silage diets. Can. J. Anim. Sci. 73:544-557.

Berthiaume, R., C. Benchaar, A. V. Chaves, G. F. Tremblay, Y. Castonguay, A. Bertrand, G. Bélanger, R. Michaud, C. Lafrenière, T. A. McAllister, and A. F. Brito. 2010. Effects of nonstructural carbohydrate concentration in alfalfa on fermentation and microbial protein synthesis in continuous culture. J. Dairy Sci. 93:693-700.

Brito, A. F., and G. A. Broderick. 2006. Effects of varying dietary ratios of alfalfa silage to corn silage on production and nitrogen utilization in lactating dairy cows. J. Dairy Sci. 89:3924-3938.

Brito, A. F., G. A. Broderick, and S. M. Reynal. 2007. Effects of different protein supplements on omasal nutrient flow and microbial protein synthesis in lactating dairy cows. J. Dairy Sci. 90:18281841.

Brito, A. F., G. F. Tremblay, H. Lapierre, A. Bertrand, Y. Castonguay, G. Belanger, R. Michaud, C. Benchaar, D. R. Ouellet, and 
R. Berthiaume. 2009. Alfalfa cut at sundown and harvested as baleage increases bacterial protein synthesis in late-lactation dairy cows. J. Dairy Sci. 92:1092-1107.

Caroprese, M., A. Marzano, R. Marino, G. Gliatta, A. Muscio, and A. Sevi. 2010. Flaxseed supplementation improves fatty acid profile of cow milk. J. Dairy Sci. 93:2580-2588.

Carro, M. D., and E. L. Miller. 1999. Effect of supplementing a fibre basal diet with different nitrogen forms on ruminal fermentation and microbial growth in an in vitro semi-continuous culture system (RUSITEC). Br. J. Nutr. 82:149-157.

Clark, J. H., T. H. Klusmeyer, and M. R. Cameron. 1992. Microbial protein synthesis and flows of nitrogen fractions to the duodenum of dairy cows. J. Dairy Sci. 75:2304-2323.

Coblentz, W. K., I. E. O. Abdelgadir, R. C. Cochran, J. O. Fritz, W. H. Fick, K. C. Olson, and J. E. Turner. 1999. Degradability of forage proteins by in situ and in vitro enzymatic methods. J. Dairy Sci. 82:343-354.

Fernando, S. C., H. T. Purvis II, F. Z. Najar, L. O. Sukharnikov, C. R. Krehbiel, T. G. Nagaraja, B. A. Roe, and U. DeSilva. 2010. Rumen microbial population dynamics during adaptation to a highgrain diet. Appl. Environ. Microbiol. 76:7482-7490.

Fieser, B. G., and E. S. Vanzant. 2004. Interactions between supplement energy source and tall fescue hay maturity on forage utilization by beef steers. J. Anim. Sci. 82:307-318.

Gregorini, P., K. J. Soder, and G. Waghorn. 2010. Effects of timing of corn silage supplementation on digestion, fermentation pattern, and nutrient flow during continuous culture fermentation of a short and intensive orchardgrass meal. J. Dairy Sci. 93:3722-3729.

Griswold, K. E., W. H. Hoover, T. K. Miller, and W. V. Thayne. 1996 Effect of form of nitrogen on ruminal microbes in continuous culture. J. Anim. Sci. 74:483-491.

Hall, M. B., W. H. Hoover, J. P. Jennings, and T. K. Miller Webster. 1999. A method for partitioning neutral detergent-soluble carbohydrates. J. Sci. Food Agric. 79:2079-2086.

Hoover, W. H., T. K. Miller, S. R. Stokes, and W. V. Thayne. 1989. Effects of fish meals on rumen bacterial fermentation in continuous culture. J. Dairy Sci. 72:2991-2998.

Kronberg, S. L., E. J. Scholljegerdes, A. N. Lepper, and E. P. Berg 2011. The effect of flaxseed supplementation on growth, carcass characteristics, fatty acid profile, retail shelf life, and sensory characteristics of beef from steers finished on grasslands of the northern Great Plains. J. Anim. Sci. 89:2892-2903.

Martin, C., J. Rouel, J. P. Jouany, M. Doreau, and Y. Chilliard. 2008. Methane output and diet digestibility in response to feeding dairy cows crude linseed, extruded linseed, or linseed oil. J. Anim. Sci. $86: 2642-2650$

Mirzaei-Aghsaghali, A., and N. Maheri-Sis. 2011. Factors affecting mitigation of methane emission from ruminants I: Feeding strategies. Asian J. Anim. Vet. Adv. 6:888-908.

Mrázek, J., K. Tepšič, G. Avguštin, and J. Kopečný. 2006. Diet-dependent shifts in ruminal butyrate-producing bacteria. Folia Microbiol. (Praha) 51:294-298.

NRC. 2001. Nutrient Requirements of Dairy Cattle. 7th rev. ed. Nat. Acad. Sci. Washington, DC.
O'Neill, B. F., M. H. Deighton, B. M. O'Loughlin, F. J. Mulligan, T. M. Boland, M. O'Donovan, and E. Lewis. 2011. Effects of a perennial ryegrass diet or total mixed ration diet offered to springcalving Holstein-Friesian dairy cows on methane emissions, dry matter intake, and milk production. J. Dairy Sci. 94:1941-1951.

Oldick, B. S., J. L. Firkins, and N. R. St-Pierre. 1999. Estimation of microbial nitrogen flow to the duodenum of cattle based on dry matter intake and diet composition. J. Dairy Sci. 82:1497-1511.

Petit, H. V. 2010. Milk production and milk composition of dairy cows fed flaxseed: A review. Can. J. Anim. Sci. 90:115-127.

Ross, S., A. F. Brito, K. J. Soder, K. Greene, A. Green, and P. Y. Chouinard. 2011. Effect of molasses or cornmeal on milk production and nitrogen utilization of grazing organic dairy cows. J. Dairy Sci. 94(E-Suppl. 1):317. (Abstr.)

Scholljegerdes, E. J., and S. L. Kronberg. 2010. Effect of supplemental ground flaxseed fed to beef cattle grazing summer native range on the northern Great Plains. J. Anim. Sci. 88:2108-2121.

Soder, K. J., A. F. Brito, M. D. Rubano, and C. J. Dell. 2012. Effect of incremental flax supplementation of an herbage diet on methane output and ruminal fermentation in continuous culture. J. Dairy Sci. 95:3961-3969.

Soder, K. J., and L. D. Muller. 2007. Case study: Use of partial total mixed rations on pasture-based dairy farms in Pennsylvania and New York. Prof. Anim. Sci. 23:300-307.

Van Soest, P. J., J. B. Robertson, and B. A. Lewis. 1991. Methods for dietary fiber, neutral detergent fiber and nonstarch polysaccharides in relation to animal nutrition. J. Dairy Sci. 74:3583-3597.

Vibart, R. E., J. C. Burns, and V. Fellner. 2010. Effect of replacing total mixed ration with pasture on ruminal fermentation. Prof. Anim. Sci. 26:435-442.

Vibart, R. E., V. Fellner, J. C. Burns, G. B. Huntington, and J. T. Green. 2008. Performance of lactating dairy cows fed varying levels of total mixed ration and pasture. J. Dairy Res. 75:471-480.

Wales, W. J., E. S. Kolver, and A. R. Egan. 2009. Digestion during continuous culture fermentation when replacing perennial ryegrass with barley and steam-flaked corn. J. Dairy Sci. 92:189-196.

Weller, R. A., and A. F. Pilgrim. 1974. Passage of protozoa and volatile fatty acids from the rumen of the sheep and from a continuous in vitro fermentation system. Br. J. Nutr. 32:341-351.

White, S. L., G. A. Benson, S. P. Benson, and J. T. Green Jr. 2002. Milk production and economic measures in confinement or pasture systems using seasonally calved Holstein and Jersey cows. J. Dairy Sci. 85:95-104.

Yang, C. M. J., and G. A. Varga. 1989. Effect of three concentrate feeding frequencies on rumen protozoa, rumen digesta kinetics, and milk yields in dairy cows. J. Dairy Sci. 72:950-957.

Zachut, M., A. Arieli, H. Lehrer, L. Livshitz, S. Yakoby, and U. Moallem. 2010. Effects of increased supplementation of n-3 fatty acids to transition dairy cows on performance and fatty acid profile in plasma, adipose tissue, and milk fat. J. Dairy Sci. 93:5877-5889.

Zinn, R. A., and F. N. Owens. 1986. A rapid procedure for purine measurement and its use for estimating net ruminal protein synthesis. Can. J. Anim. Sci. 66:157-166. 